Article

\title{
Socio-Emotional Competence and Self-Efficacy of Future Secondary School Teachers
}

\author{
Romero-García Carmen $^{1, *(\mathbb{D})}$, Buzón-García Olga ${ }^{2}$ (D) and Marcano Beatriz ${ }^{1}$ (D) \\ 1 Faculty of Education, Universidad Internacional de La Rioja, 28040 Madrid, Spain; beatriz.marcano@unir.net \\ 2 Faculty of Education Sciencies, Universidad de Sevilla, 41013 Seville, Spain; obuzon@us.es \\ * Correspondence: mariadelcarmen.romero@unir.net
}

Citation: Carmen, R.-G.; Olga, B.-G.; Beatriz, M. Socio-Emotional

Competence and Self-Efficacy of

Future Secondary School Teachers.

Educ. Sci. 2022, 12, 161. https://

doi.org/10.3390/educsci12030161

Academic Editor: Ching Sing Chai

Received: 28 January 2022

Accepted: 23 February 2022

Published: 25 February 2022

Publisher's Note: MDPI stays neutral with regard to jurisdictional claims in published maps and institutional affiliations.

Copyright: (c) 2022 by the authors. Licensee MDPI, Basel, Switzerland. This article is an open access article distributed under the terms and conditions of the Creative Commons Attribution (CC BY) license (https:// creativecommons.org/licenses/by/ $4.0 /)$.

\begin{abstract}
The assessment and development of teachers' socio-emotional competence has become a topic of interest in education. Within the classroom, this competence is demonstrated not only in teaching but also in student development. The present study addressed the relationship between socio-emotional competence and self-efficacy, as perceived by prospective secondary-school teachers $(n=285)$ studying for a master's degree in teacher training, and possible differences according to the socio-demographic characteristics of the sample. A descriptive, correlational and cross-sectional, survey-type method was followed. The instruments used were a previously validated socioemotional competence inventory, and an adapted version of the Teachers Self Efficacy Scale. The results showed an adequate level in most of the socio-emotional competencies studied and a high perception of self-efficacy, and both scales correlated positively. Higher levels of socioemotional competence were found in women and in teachers aged 40 to 50 with more teaching experience. The positive effect of experience in relation to self-efficacy being higher in women than in men was corroborated. We concluded that there is a need to develop the socio-emotional competence of trainee teachers to improve their teaching performance.
\end{abstract}

Keywords: socio-emotional competence; teacher self-efficacy; higher education; prospective secondary school teachers

\section{Introduction}

Nowadays, the demands of teachers' professional careers extend beyond the demonstration of technical and professional competence into social and emotional competence. These are necessary competences to handle various classroom situations, such as managing conflicts during classes, intervening to address learning difficulties, promoting inclusion, and performing planning and administrative tasks [1,2]. This expansion of competences was exacerbated by the pandemic of 2020 as teaching shifted from face-to-face to online teaching [3,4]. (Chitra, 2020; Hadar et al., 2020). The need to respond to student needs and manage educational institutions forced teachers to overcome their fear of change, adapt to uncertainty, manage frustration and develop a greater tolerance for individual differences, all of which fall under emotional management [5]. Remaining balanced while coping with drastic changes in education, health, sanitation conditions and in life in general demands socio-emotional competence, self-regulation, stress management, empathy, adaptability, flexibility, and problem-solving. Similarly, teachers require self-confidence and a positive perception of techno-pedagogical competencies [4,6,7] to teach effectively, and this contributes to teacher efficacy. This study analyses the perception that teachers-in-training have toward their socio-emotional competencies and the relationship with teacher self-efficacy.

\section{Theoretical Framework}

The profession of secondary-school teaching requires specific skills to be able to manage adolescents. At this stage, disruptive and violent behaviour, consumption of toxic 
substances, and difficulties in interpersonal relationships are common. These behaviours are also manifested in educational centres as well as classes and become a source of stress for the teacher $[8,9]$ in addition to stress related to keeping up to date with pedagogical knowledge and strategies, becoming overworked due to correcting homework, classroom diversity or burnout syndrome, all of which demand emotional self-regulation [10-12]. Facing all these situations requires assertive responses, awareness and emotional expression to maintain internal balance. At the same time, one must be able to show empathy and social sensitivity, particularly toward adolescents, considering all the conflicts that are typical at this evolutionary stage $[8,13]$. For all these reasons, within the educational field and especially in secondary education, the study of socio-emotional competence in teachers is important.

In this particular study, we adopted the approach of Mikulic et al. (2015) [14], who relied on Bisquerra's concept of socio-emotional competence, as a "set of knowledge, skills and attitudes necessary to understand, express and appropriately regulate emotional phenomena" (2003, p. 22) [15]. It implies that this competence can be acquired throughout life by putting knowledge, attitudes and personality traits into practice. It takes into account the interaction between a person and the environment and highlights interpersonal relationships, pointing out that they are intertwined with emotions. In this regard, he adds, "listening and the capacity for empathy open the door to pro-social attitudes, which are the antipodes of racist, xenophobic or sexist attitudes, which cause so many social problems" (p. 31). It also highlights the importance of learning and developing these competencies.

Consequently, the competencies apply to education [16]. Based on an in-depth review of the literature, Mikulic et al. (2015) [14] defined nine dimensions of socio-emotional competence and integrated those that are common in different studies [17-20]. They defined this multidimensional construct as consisting of the following dimensions: assertiveness, self-efficacy, autonomy, emotional awareness, emotional expression, empathy, optimism, pro-sociality and emotional regulation. They also validated a questionnaire for the assessment of these dimensions in different contexts [21].

As noted above, a teacher's socio-emotional competence plays an important role in the relationships established in the classroom and the method of teaching [22]. Teachers who acquire this competence are in a better position to relate positively with the educational community, thereby increasing the effectiveness of education [16,23]. In this same respect, socio-emotional competence is a focus of attention in teacher training, because it is considered to be a means to improve the quality of teaching and learning and the development of students' pro-social behaviour [24,25]. In fact, teachers trained in socio-emotional competencies have an important role to play in promoting them among students to influence sustainable social development $[2,4,6]$. It has been proven that the self-perception of socioemotional competence is related to a positive classroom climate [26]. Various research has shown the importance of teacher training in these skills to prevent absenteeism, dropping out and disruptive classroom behaviour $[27,28]$ and the need to consider the individual needs of all students (Llorent, López and Gavilán, 2012) [29]. It has been shown that the development of these competencies on students has a positive impact on learning, interpersonal relationships and academic performance $[30,31]$

In this respect, some authors consider the perception of self-efficacy to be one of the emotional competencies [14,32,33]. However, teacher self-efficacy has been considered as an element mainly related to the pedagogical and didactic skills that allow them to perform satisfactorily [7,34,35]. In addition, Covarrubias and Mendoza (2016) [36] highlighted that the feeling of positive self-efficacy has an impact on the use of various teaching strategies, on the adaptability of teaching methods towards the specific educational needs of students, on the efficient management of classroom conflicts and on the stimulation of students' participation in their own learning. This study applies this approach to teacher self-efficacy.

Previous studies established how the feeling of teacher self-efficacy affects students' ability to learn (Bandura, 1993) [37]. In fact, it favours inclusive behaviours between primary education teachers and students with special educational needs, but less so regarding 
secondary-education teachers [7]. Fernández-Viciana and Fernández-Costales (2019) [34] found an inverse relationship between perceived self-efficacy in linguistic and methodological competencies in primary-school teachers. According to the socio-cognitive view from which this construct emerges [37,38], self-efficacy is strongly conditioned by the system of beliefs that people have regarding how things should be done and how they are expected to be done. The socio-cultural context, therefore, is important for the perception of self-efficacy. Hence, training plays a fundamental role in the self-awareness of teaching skills, which, at the same time, conditions the effort devoted to the motivation and execution of tasks [39].

Given the importance of the social implications of socio-emotional competencies and how teacher self-efficacy affects students, this study explored how prospective secondaryschool teachers perceived themselves in relation to these two variables.

\section{Materials and Methods}

\subsection{Design}

In this research, a descriptive, correlational and cross-sectional survey-type methodological design was used to determine future teachers' perceptions of their level of socioemotional competencies and teacher self-efficacy.

\subsection{Objectives}

Following the analysis of the problems associated with this area of study, the present research had the following general objective: to evaluate the relationship between socioemotional competencies and self-perceived teaching effectiveness among students who are aspiring secondary-school teachers. For this, the following specific objectives were proposed:

- $\quad$ To explore the level of socio-emotional competencies and teacher self-efficacy using validated instruments;

- $\quad$ To determine whether socio-emotional competencies are significantly correlated with teacher self-efficacy;

- $\quad$ To determine possible differences in socio-emotional competencies and self-efficacy according to the socio-demographic variables of the prospective teachers.

Based on these objectives, we put forward the following hypotheses:

- Socio-emotional competencies correlate positively with teacher self-efficacy;

- Socio-demographic variables influence the self-perception of socio-emotional competence and the perception of teaching self-efficacy.

\subsection{Population and Sample}

The study population comprised students who attended an on-line master's degree program in teacher training for compulsory secondary education and baccalaureate, vocational training and language teaching $(n=1100)$, during the 2019-2020 academic year, at the International University of La Rioja. The sample used was non-probabilistic by convenience, and the resulting sample consisted of 285 students from different autonomous communities, (61.40\% women and $38.60 \%$ men) aged between 20 and 63 . In this respect, $28.4 \%$ were between 20 and 30, 40\% between 31 and $40,28.4 \%$ between 41 and 50, and $3.2 \%$ over 50 . As for their level of education, $4.21 \%$ had a doctorate, $40.35 \%$ a master's degree, $53.68 \%$ a bachelor's degree, $0.35 \%$ had received intermediate vocational training and the remaining $0.35 \%$ had higher vocational training. With regard to previous teaching experience, $69.5 \%$ had none, $11.9 \%$ had less than 1 year, $9.8 \% 1-3$ years, and $8.8 \%$ had 4 or more years.

The participants were informed of the objectives of the research and were guaranteed anonymity. All of them agreed. 


\subsection{Instrument}

The previously validated Socioemotional Competence Inventory [14], a psychometric instrument, was used to collect information on the perception of the level of socio-emotional competence. It assesses the following nine competencies: self-efficacy (SE), optimism (OP), assertiveness (AS), emotional expression (EE), emotional awareness (EA), empathy (EM), emotional regulation (ER), pro-sociality (PR) and autonomy (AU). It consists of 72 items, rated according to a Likert scale (1, completely disagree; 2 , disagree; 3, neither agree nor disagree; 4, agree; and 5, completely agree). A reliability analysis of the instrument was performed, obtaining a Cronbach's alpha of 0.932. Therefore, it was considered that the instrument had adequate reliability.

The instrument used to measure teacher self-efficacy was an adapted version of the Teachers Self Efficacy Scale (TSES) of Tschannen-Moran and Woolfolk (2001) [40] by Covarrubias and Mendoza (2016) [36]; this tool is valid and reliable and explains the theory of teacher self-efficacy, which is divided into the following four dimensions: efficacy in teaching and learning strategies (ETS), efficacy in classroom management (ECM), efficacy in student engagement (ESE) and efficacy in attending to students' uniqueness (EAS). It consists of 17 items that are rated according to a Likert scale (1, not at all; 2, not at all, 3 , somewhat; 4 , quite a lot; and 5, very much,). The reliability analysis of the instrument was carried out, obtaining a Cronbach's alpha of 0.919. Therefore, the instrument was considered adequately reliable.

\subsection{Data Collection and Analysis Procedure}

The questionnaire was sent out to students online upon completion of the master's degree in teacher's training, and the study was conducted in accordance with the ethical guidelines for research.

Firstly, descriptive statistics were calculated to determine the general characteristics of the selected sample, as well as the scores of the dimensions of socio-emotional competence and teacher self-efficacy.

In addition, correlational analyses were carried out to determine the relation of socioemotional competencies to teacher-perceived self-efficacy, using Spearman's rho correlation coefficient.

Possible differences in the dimensions of socio-emotional competence and self-efficacy were considered by taking into account socio-demographic variables such as sex, age of the teacher and years of teaching experience. Non-parametric tests, the Mann-Whitney U test and the Kruskal-Wallis test, were used since the variables did not conform to a normal distribution. The normality of the sample was determined using the Kolmogorov-Smirnov test with the Lillefors correction and the Shapiro-Wilk test.

In addition, for all significant comparisons, effect sizes were calculated using r, Pearson's correlation coefficient, for two groups, or the $\eta^{2}$ statistic when more than two groups were considered. Values of $r=0.10$ were considered as low; $r=0.3$ medium; $r=0.5$ large; and $r=0.7$ very large [41]. For $\eta^{2}$ for more than two groups, values around 0.01 had a small effect, 0.06 had a medium effect and if it reached 0.14 , it was considered a large effect. Data were organised, coded and analysed using the SPSS 26.0 statistical package.

\section{Results}

A descriptive analysis of the self-perception scale of socio-emotional competencies was carried out, showing that the most predominant were emotional awareness (EA 4.10), optimism (OP 4.09), pro-sociality (PR 3.95) and empathy (EM 3.88) (Figure 1). 


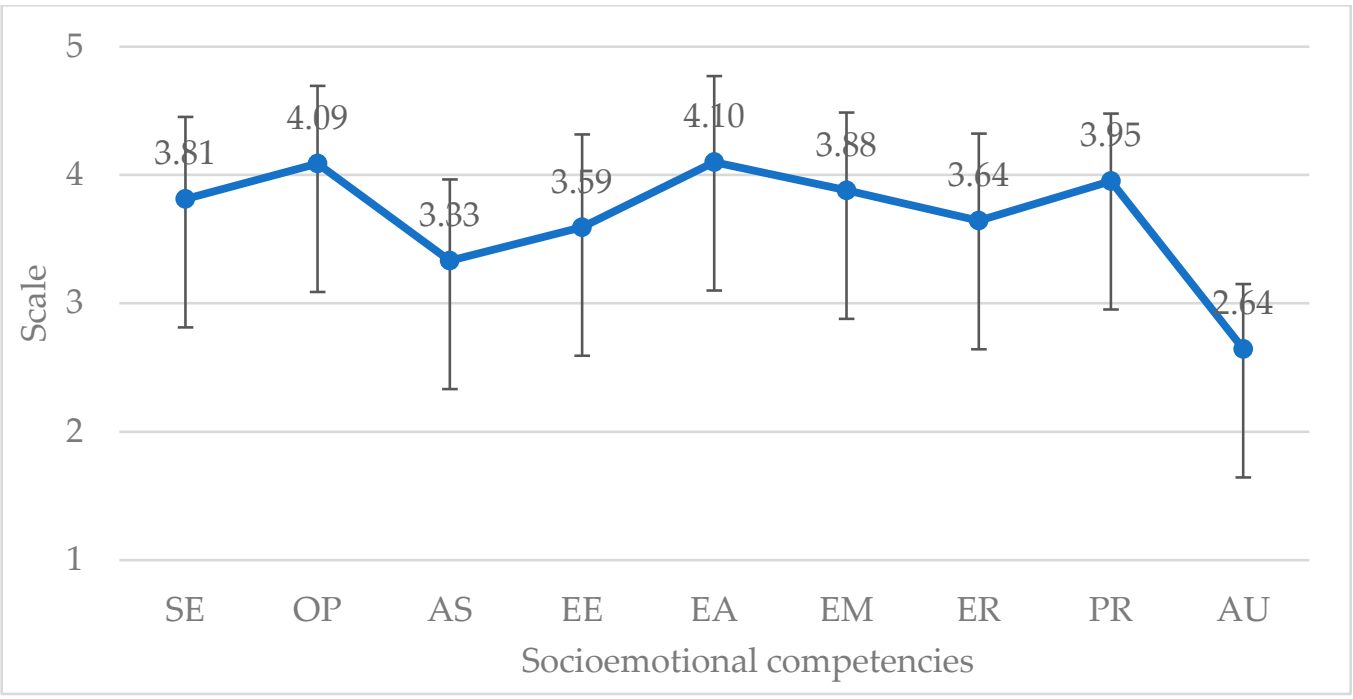

Figure 1. Means and standard deviations of socio-emotional competencies.

On the other hand, the results of the teacher self-efficacy scale (Figure 2) showed a high level of self-efficacy given that all the dimensions reached values above 3.6. Specifically, we found that the dimensions in which students had the highest scores were those related to student engagement (ESE 4.18) and teaching and learning strategies (ETS 4.12).

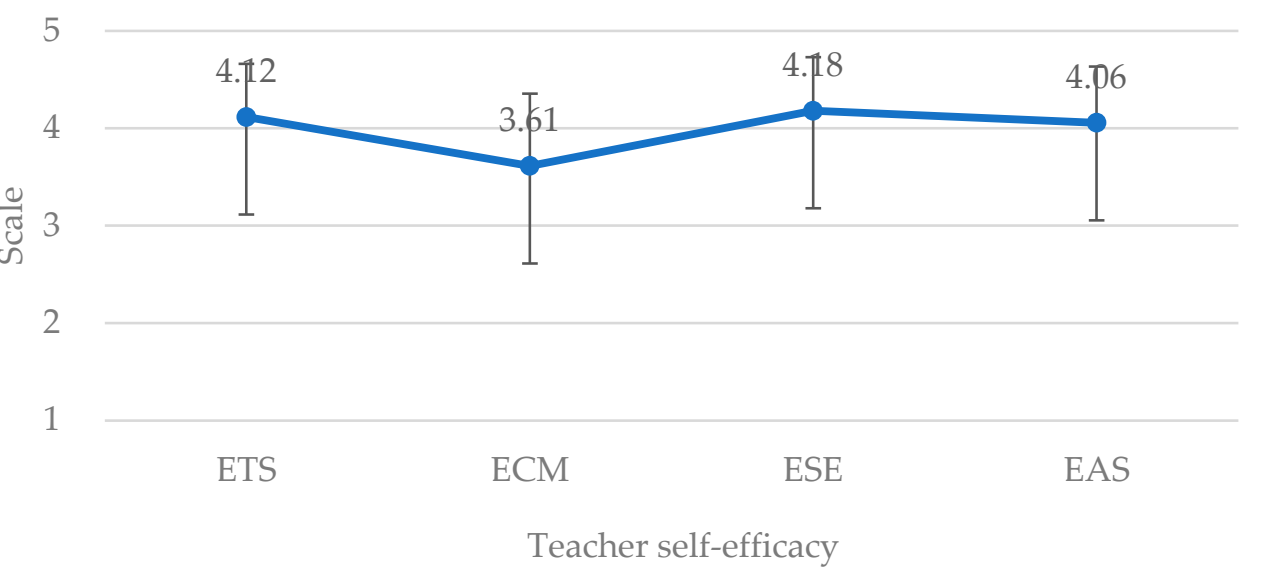

Figure 2. Means and standard deviations of the dimensions of the teacher self-efficacy scale.

We studied whether there was any correlation between socioemotional competence and teacher self-efficacy. To do so, we first applied the Kolmogorov-Smirnov test with the Lillefors correction and the Shapiro-Wilk test to check whether the scores on both scales had a normal distribution. The results indicated that for the teacher self-efficacy scale, $p<0.05$, while for the socio-emotional competence, $p>0.05$ (Table 1 ). Therefore, non-parametric tests were performed, specifically Spearman's rho test, so as to correlate the results.

Table 1. Kolmogorov-Smirnov normality test.

\begin{tabular}{cccc}
\hline & Statistical & gl & $p$ \\
\hline Socio-emotional competence & 0.030 & 285 & 0.200 \\
Teacher self-efficacy & 0.054 & 285 & 0.042 \\
\hline
\end{tabular}


As can be seen in Table 2, all the dimensions of teacher self-efficacy correlated, to a greater or lesser extent, with some socio-emotional competencies. Among them, we can highlight how efficacy in teaching and learning strategies (ETS) correlated more with certain socio-emotional competencies such as self-efficacy $(r=0.336)$ and emotional regulation $(\mathrm{r}=0.209)$. Efficacy in classroom management $(\mathrm{ECM})$ only correlated with emotional expression $(r=0.285)$, assertiveness $(r=0.274)$, optimism $(r=0.270)$ and self-efficacy $(r=0.228)$. On the other hand, efficacy in student engagement (ESE) had higher correlations with self-efficacy $(r=0.312)$, optimism $(r=0.308)$ and emotional expression $(r=0.285)$. Finally, efficacy in attending to students' uniqueness (EAS) correlated to a higher degree with assertiveness $(r=0.308)$, self-efficacy $(r=0.253)$ and emotional expression $(r=0.250)$.

Table 2. Correlations between socio-emotional competencies and teacher self-efficacy.

\begin{tabular}{|c|c|c|c|c|c|}
\hline \multirow{2}{*}{$\begin{array}{l}\text { Socio-Emotional } \\
\text { Competencies }\end{array}$} & & \multicolumn{4}{|c|}{ Teacher Self-Efficacy } \\
\hline & & ETS & ECM & ESE & EAS \\
\hline \multirow{2}{*}{ Self-efficacy } & Correlation coefficient & $0.336^{* *}$ & $0.228 * *$ & $0.312 * *$ & $0.253^{* *}$ \\
\hline & Sig. (bilateral) & 0.000 & 0.000 & 0.000 & 0.000 \\
\hline \multirow{2}{*}{ Optimism } & Correlation coefficient & $0.279 * *$ & $0.270 * *$ & $0.308 * *$ & $0.241^{* *}$ \\
\hline & Sig. (bilateral) & 0.000 & 0.000 & 0.000 & 0.000 \\
\hline \multirow[b]{2}{*}{ Assertiveness } & Correlation coefficient & $0.242^{* *}$ & $0.274^{* *}$ & $0.236^{* *}$ & $0.308^{* *}$ \\
\hline & Sig. (bilateral) & 0.000 & 0.000 & 0.000 & 0.000 \\
\hline \multirow{2}{*}{ Emotional expression } & Correlation coefficient & $0.234^{* *}$ & $0.285^{* *}$ & $0.268^{* *}$ & $0.250 * *$ \\
\hline & Sig. (bilateral) & 0.000 & 0.000 & 0.000 & 0.000 \\
\hline \multirow{2}{*}{ Emotional awareness } & Correlation coefficient & $0.272^{* *}$ & $0.178^{* *}$ & $0.278^{* *}$ & $0.248^{* *}$ \\
\hline & Sig. (bilateral) & 0.000 & 0.003 & 0.000 & 0.000 \\
\hline \multirow{2}{*}{ Empathy } & Correlation coefficient & $0.175^{* *}$ & -0.010 & $0.162 * *$ & 0.083 \\
\hline & Sig. (bilateral) & 0.003 & 0.865 & 0.006 & 0.161 \\
\hline \multirow{2}{*}{ Emotional regulation } & Correlation coefficient & $0.209 * *$ & 0.060 & $0.127 *$ & $0.128 *$ \\
\hline & Sig. (bilateral) & 0.000 & 0.315 & 0.032 & 0.030 \\
\hline \multirow{2}{*}{ Pro-sociability } & Correlation coefficient & $0.189 * *$ & 0.068 & $0.184^{* *}$ & $0.154^{* *}$ \\
\hline & Sig. (bilateral) & 0.001 & 0.250 & 0.002 & 0.009 \\
\hline \multirow{2}{*}{ Autonomy } & Correlation coefficient & $-0.148 *$ & 0.067 & -0.014 & -0.102 \\
\hline & Sig. (bilateral) & 0.012 & 0.261 & 0.812 & 0.084 \\
\hline
\end{tabular}

** The correlation is significant at the 0.01 level. * The correlation is significant at the 0.05 level.

Possible differences in socio-emotional competencies and teacher self-efficacy were examined by taking into account some of the socio-demographic variables such as sex, age and years of teaching experience. For this purpose and given that the variables did not fit a normal distribution, non-parametric tests were used, such as the Mann-Whitney U test for sex and the Kruskal-Wallis H-test for age and teaching experience.

To find out if there were differences in the socio-emotional competencies according to sex (Figure 3), the Mann-Whitney U test was applied. It was observed that women achieved a higher average range than men in all competencies. However, statistically significant differences were only established in the competencies of self-efficacy $(z=-2.091, p=0.037$, $r=0.12)$, emotional expression $(z=-3.580, p=0.000, r=0.21)$, emotional awareness $(\mathrm{z}=-4.337, p=0.000, \mathrm{r}=0.25)$ and pro-sociality $(\mathrm{z}=-3.432, p=0.001, \mathrm{r}=0.20)$, with low-effect sizes in all of them. 


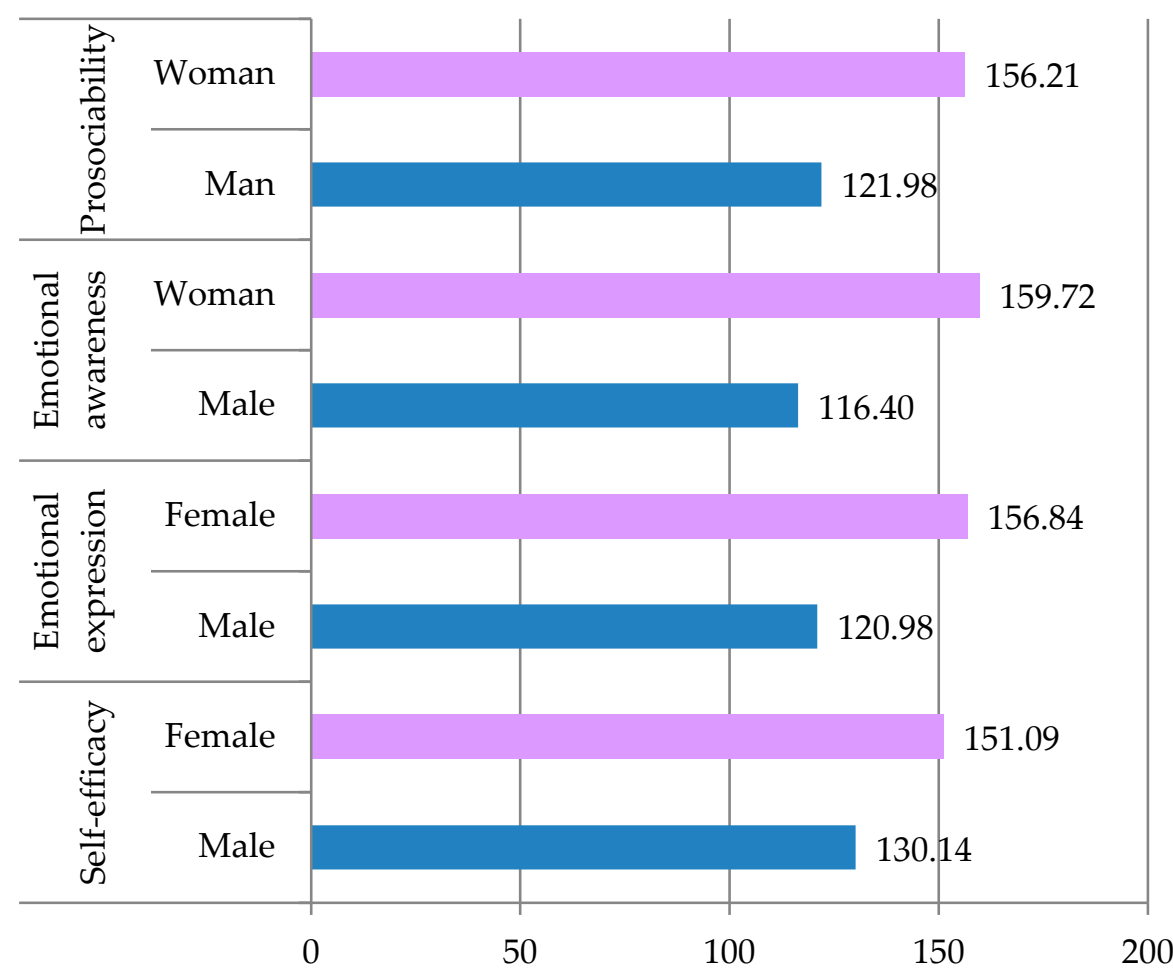

Figure 3. Average range of socio-emotional competencies according to sex.

The Kruskal-Wallis H-test was applied to analyse whether age had an influence on socio-emotional competencies, and statistically significant differences were found between the four established age ranges (20-30, 31-40, 41-50 and over 50), and some of the socioemotional competencies such as self-efficacy $(p=0.003)$, optimism $(p=0.001)$, emotional expression $(p=0.019)$ and empathy $(p=0.011)$.

Looking at the average ranges (Table 3 ), the differences were the lowest for self-efficacy and optimism in the 20-30 range (124.87 and 116.88, respectively) and 41-50 (171.22 and 170.72 , respectively). In the case of emotional expression, differences were found between 20-30 (129.07) and for those over 50 (189.89), which constitute the highest average range. As for empathy, differences were found between 41-50 (166.31) and over 50 (95.78), which was the highest average range.

Table 3. Average range of socio-emotional competencies according to age.

\begin{tabular}{cccc}
\hline Competencies Socio-Emotional & Age & $\mathbf{N}$ & Average Range \\
\hline \multirow{2}{*}{ Self-efficacy } & 20 to 30 years & 81 & 124.87 \\
& 31 to 40 years & 114 & 136.79 \\
& 41 to 50 years & 81 & 171.22 \\
& $>50$ years & 9 & 130.78 \\
\hline Optimism & 20 to 30 years & 81 & 116.88 \\
& 31 to 40 years & 114 & 141.67 \\
& 41 to 50 years & 81 & 170.72 \\
Expression emotional & $>50$ years & 9 & 145.44 \\
& 20 to 30 years & 81 & 129.07 \\
& 31 to 40 years & 114 & 136.28 \\
& 41 to 50 years & 81 & 161.17 \\
& $>50$ years & 9 & 189.89 \\
\hline
\end{tabular}


The Kruskal-Wallis H-test was applied and statistically significant differences were found between years of teaching experience and two of the socioemotional competencies. Optimism $(p=0.029)$ and pro-sociability $(p=0.031)$.

Observing the average ranges (Table 4), we can state that there were differences found in optimism between subjects with no experience (136.05) and those with 4 years or more (187.62), in favour of the latter. In the case of pro-sociability, differences were found between those with no experience (136.39) and those with between 1 and 3 years of experience (182.30), who constituted those with the highest average ranges.

Table 4. Average range of socio-emotional competencies according to years of teaching experience.

\begin{tabular}{cccc}
\hline $\begin{array}{c}\text { Competencies } \\
\text { Socio-Emotional }\end{array}$ & $\begin{array}{c}\text { Years of Teaching } \\
\text { Experience }\end{array}$ & $\mathbf{N}$ & Average Range \\
\hline \multirow{2}{*}{ Optimism } & Inexperienced & 198 & 136.05 \\
& Less than one year & 34 & 145.01 \\
& $1-3$ years & 28 & 149.84 \\
& 4 years or more & 25 & 187.62 \\
\hline \multirow{2}{*}{ Pro-sociability } & Inexperienced & 198 & 136.39 \\
& Less than one year & 34 & 137.24 \\
& $1-3$ years & 28 & 182.30 \\
\end{tabular}

To assess whether sex had an influence on teacher self-efficacy (Table 5), the MannWhitney $\mathrm{U}$ test was applied, revealing that women achieved a higher average range compared to men in all dimensions, although they established statistically significant differences only in the IES dimension $(\mathrm{z}=-2.338, p=0.019)$, with a low effect size $(\mathrm{r}=0.14)$.

Table 5. Average range of teacher self-efficacy by sex.

\begin{tabular}{cccccccc}
\hline Teacher Self-Efficacy & Sex & N & $\begin{array}{c}\text { Average } \\
\text { Range }\end{array}$ & $\begin{array}{c}\text { Sum of } \\
\text { Ranges }\end{array}$ & Z & $\begin{array}{c}\text { Asymptotic Sign } \\
\text { (Bilateral) }\end{array}$ & Effect Size \\
\hline $\begin{array}{c}\text { In Student Engagement } \\
\text { (ESE) }\end{array}$ & Man & 110 & 128.76 & $14,163.50$ & & 0.019 & 0.14 \\
\cline { 2 - 5 } & Woman & 175 & 151.95 & $26,591.50$ & -2.338 & 0.000 \\
\hline
\end{tabular}

Regarding the influence of age on teacher self-efficacy, no statistically significant differences were found.

Finally, we analysed whether years of teaching experience influenced teacher selfefficacy. We applied the Kruskal-Wallis H-test and found statistically significant differences between years of teaching experience and all dimensions of teacher self-efficacy ETS $(p=0.013), \operatorname{ECM}(p=0.013), \operatorname{ESE}(p=0.001)$ and $\operatorname{EAS}(p=0.003)$.

Looking at the average ranges (Table 6 ), there were differences in the effectiveness in the ETS between subjects with no experience (134.38) and those with 4 years or more (188.60), in favour of the latter. Regarding ECM effectiveness, differences were found between those with no experience (134.12) and those with 4 or more years (186.90), who had the highest average range. On the other hand, in ESE effectiveness, differences were again found between those with no experience (133.55) and those with 4 years of experience or more (200.00) who reached a higher average range. Finally, in EAS effectiveness, we again found differences between those with no experience (132.03) and those with 4 years or more (187.22), with the latter having the highest average range. 
Table 6. Average ranges of teacher self-efficacy as a function of years of teaching experience.

\begin{tabular}{|c|c|c|c|}
\hline Teacher Self-Efficacy & $\begin{array}{l}\text { Years of Teaching } \\
\text { Experience }\end{array}$ & $\mathbf{N}$ & Average Range \\
\hline \multirow{4}{*}{$\begin{array}{l}\text { In teaching and } \\
\text { learning strategies } \\
\text { (ETS) }\end{array}$} & Inexperienced & 198 & 134.38 \\
\hline & less than one year & 34 & 150.69 \\
\hline & $1-3$ years & 28 & 153.88 \\
\hline & 4 years or more & 25 & 188.60 \\
\hline \multirow{4}{*}{$\begin{array}{c}\text { In classroom } \\
\text { management (ECM) }\end{array}$} & Inexperienced & 198 & 134.12 \\
\hline & Less than one year & 34 & 149.10 \\
\hline & $1-3$ years & 28 & 159.16 \\
\hline & 4 years or more & 25 & 186.90 \\
\hline \multirow{4}{*}{$\begin{array}{c}\text { In student } \\
\text { engagement (ESE) }\end{array}$} & Inexperienced & 198 & 133.55 \\
\hline & Less than one year & 34 & 146.60 \\
\hline & $1-3$ years & 28 & 154.55 \\
\hline & 4 years or more & 25 & 200.00 \\
\hline \multirow{4}{*}{$\begin{array}{c}\text { In attending to a } \\
\text { student's uniqueness } \\
(\text { EAS) }\end{array}$} & Inexperienced & 198 & 132.03 \\
\hline & Less than one year & 34 & 158.34 \\
\hline & 1-3 years & 28 & 162.46 \\
\hline & 4 years or more & 25 & 187.22 \\
\hline
\end{tabular}

\section{Discussion}

Traditionally, the learning achievements of university students have focused on cognitive aspects. However, different studies have highlighted the influence of social and emotional skills on academic performance $[23,30,31]$. The assessment and development of socio-emotional competence has become a topic of interest in higher education. Specifically, the socio-emotional competence of future teachers influences the way they teach as well as the development of these competencies in their students $[4,6,25]$. For this reason, the present study addressed the relationship between socio-emotional competencies and teacher self-efficacy, as perceived by students upon their completion of the master's degree in teacher training for secondary education.

Firstly, an adequate level was determined in most of the socio-emotional competencies. The competencies that were above average were emotional awareness (knowledge of emotions), optimism (ability to maintain a positive attitude), pro-sociality (actions taken for the benefit of others) and empathy (reaction to the emotional state of others). It seemed that teachers developed fairly acceptable socio-emotional competencies, which could lead to emotionally competent students. However, the levels observed could be improved so as to be high or very high. These results were in line with those provided by Piovano et al. (2020) [23], who determined above-average levels in the emotional awareness and pro-social competencies in a study conducted with university students using the same instrument. In relation to these results, Rojas et al. (2017) [22] determined the need to strengthen emotional awareness, emotional regulation and social competencies in future teachers, given the impact they have on teaching, and determined high levels of emotional awareness but not of emotional regulation since no relationship was established between emotion, cognition and behaviour.

With regard to teacher self-efficacy related to the skill of the teaching staff, students perceived a high level of self-efficacy related to classroom teaching and learning strategies. A high level of self-efficacy was also perceived in relation to the involvement of students and the teacher's ability to motivate them, as well as the attention paid to the uniqueness of the students. The dimension of efficacy in classroom management was below average. The detected levels of teacher self-efficacy allowed for the use of varied teaching strategies to motivate students regardless of interests and needs [7-36]. This was important, as studies have concluded that the lack of adequate methodological strategies in novice teachers can determine their future professional practice and that they may even consider quitting teaching [42]. In any case, studies by Fernández-Viciana and Fernández-Costales 
(2019) [34] determined that self-efficacy in trainee teachers is higher than in practising teachers, possibly due to direct classroom experiences. Teacher self-efficacy is an important construct in future teachers as it lasts over time and is resistant to change, acting as a long-term element in their professional practice.

With regard to the relationship of socio-emotional competencies to the self-efficacy of future secondary-school teachers, the two scales used showed a significant relationship between emotional expression (the ability to express thoughts and emotions clearly), emotional regulation (control of emotions), assertiveness (ability to express opposition appropriately), optimism, and teaching self-efficacy (ability to organise the class pedagogically, motivate students, and manage the class taking into consideration the uniqueness of the students). Similar results have been provided by Barrientos et al. (2020) [26] and Pegalajar and López (2015) [24] in a study of early childhood education teachers, in which they conclude that socio-emotional competencies may influence their classroom methodology, and by Llorent et al. (2012) [29], who related them with the ability to meet the individual needs of students.

In this study, the different nature of socio-emotional competencies and teaching efficacy in relation to sex, age and years of teaching experience was addressed. Women had higher levels in all socio-emotional competencies, with significant differences in self-efficacy (the ability to achieve desired goals), emotional expression, emotional awareness and prosociability. These results were in agreement with those of Piovano et al. (2020) [23], who found higher levels of emotional expression and pro-sociality in women and those of Llorent et al. (2020) [27], who found that women were more socio-emotionally competent than men, having higher scores in emotional self-awareness and pro-sociality. However, these authors found higher levels of emotional regulation in men. When the effect of age on socioemotional competencies was studied, older students (between 40 and 50) had higher self-efficacy, optimism, emotional expression and empathy. It seems that age has a positive effect on some emotional competencies, as was also shown by Mikulic et al. (2017) [21] and Llorent et al. (2020) [27], the latter finding greater emotional control in teachers aged over 47. It is possible that the effects of learning and practice have an effect on the regulation and control of emotions. Finally, teacher experience has a positive effect on the level of certain socio-emotional competencies, such as optimism and pro-social skills, possibly because more experienced teachers have acquired them. On the other hand, a positive effect of years of teaching experience showed that all dimensions that determine teaching efficacy were higher in women than in men. This was possibly influenced by the higher level of socio-emotional competencies.

Although this study is a first approach to the study of socio-emotional competencies in relation to teacher self-efficacy, it has some limitations such as the size of the sample and the type of sampling. For this reason, the aim was not to generalise the results, but rather to contribute to an understanding of the extent to which socioemotional competencies affect perceived teacher self-efficacy. The results allow us to propose future studies aimed at developing these competencies through training programmes, which should be adapted to the specific characteristics of the teacher, especially with regard to age and years of experience.

\section{Conclusions}

We conclude that the level of self-perceived socio-emotional competence correlates positively with perceived teacher self-efficacy. On the other hand, the variables of sex, age and teaching experience influenced the level of self-perception. In terms of the selfperception of teacher self-efficacy, we only found differences for sex and age.

Therefore, we consider it necessary to develop the socio-emotional competencies of trainee teachers to improve their teaching performance and develop skills to help them to manage the classroom appropriately. This will contribute to procuring a safe, balanced and trusting environment that favours assertiveness, empathy and self-esteem and the implementation of appropriate teaching and learning strategies to increase the performance 
of their students. In this sense, the university context is a privileged space for linking the cognitive and emotional aspects in the curricula. The development of training programmes in emotional competencies should be considered an important element for improving education.

Author Contributions: Conceptualisation, M.B.; methodology, R.-G.C. and B.-G.O.; formal analysis, B.-G.O.; research, R.-G.C., B.-G.O. and M.B.; data curation, B.-G.O.; writing-preparation of first draft, R.-G.C., B.-G.O. and M.B.; writing-revision and editing, R.-G.C., B.-G.O. and M.B.; supervision, R.-G.C.; project administration, R.-G.C.; acquiring funding, R.-G.C. All authors have read and agreed to the published version of the manuscript.

Funding: This research project was funded by the Vice-Rectorate of Research of the Universidad Internacional de la Rioja in the 2019-2020 call.

Institutional Review Board Statement: The study was conducted in accordance with the NSD cf. EUROPEAN PARLIAMENT AND COUNCIL REGULATION (EU) 2016/679 of 27 April 2016. We did not gather any personal identifiable information, and is therefore, according to NSD, not subject to ethical approval.

Informed Consent Statement: Informed consent was obtained from all subjects involved in the study.

Data Availability Statement: The data presented in this study are available on request from the corresponding author. The data are not publicly available at the participants' requests.

Conflicts of Interest: The authors declare no conflict of interest.

\section{References}

1. Knigge, M.; Krauskopf, K.; Wagner, S. Improving socio-emotional competencies using a staged video-based learning program? Results of two experimental studies. Front. Educ. 2019, 4, 142. [CrossRef]

2. Santamaría-Villar, M.B.; Gilar-Corbi, R.; Pozo-Rico, T.; Castejón, J.L. Teaching Socio-Emotional Competencies Among Primary School Students: Improving Conflict Resolution and Promoting Democratic Co-existence in Schools. Front. Psychol. 2021, 12, 2344. [CrossRef] [PubMed]

3. Chitra, A. Study on Impact of Occupational Stress on Job Satisfaction of Teachers during Covid-19 Pandemic Period. Glob. Dev. Rev. 2020, 4, 52-62.

4. Hadar, L.L.; Ergas, O.; Alpert, B.; Ariav, T. Rethinking teacher education in a VUCA world: Student teachers' social-emotional competencies during the Covid-19 crisis. Eur. J. Teach. Educ. 2020, 43, 573-586. [CrossRef]

5. García, L. Los saberes y competencias docentes en educación a distancia y digital. Una reflexión para la formación. RIED. Rev. Iberoam. Educ. Distancia 2020, 23, 9-30. [CrossRef]

6. Zaragoza, M.C.; Díaz-Gibson, J.; Caparrós, A.F.; Solé, S.L. The teacher of the 21st century: Professional competencies in Catalonia today. Educ. Stud. 2021, 47, 217-237. [CrossRef]

7. Collado, A.; Tárraga, R.; Lacruz, I.; Sanz, P. Análisis de actitudes y autoeficacia percibida del profesorado ante la educación inclusiva. Educar 2020, 56, 509-523. [CrossRef]

8. Kavita, K.; Hassan, N.C. Work stress among teachers: A comparison between primary and secondary school teachers. Int. J. Acad. Res. Progress. Educ. Dev. 2018, 7, 60-66. [CrossRef]

9. Rodríguez-Mantilla, J.M.; Fernández-Díaz, M.J. The effect of interpersonal relationships on burnout syndrome in Secondary Education teachers. Psicothema 2017, 29, 370-377. [CrossRef]

10. Jennings, P.; Brown, J.; Frank, J.; Tanler, R.; Doyle, S.; Rasheed, D.; Greenberg, M. Promoting Teachers' Social and Emotional Competence: A Replication Study of the Cultivating Awareness and Resilience in Education (CARE) Program. (conference session) The Society for Research on Educational Effectiveness (SREE) Spring 2014 Conference. Available online: https:/ / eric.ed. gov / ?id=ED562749 (accessed on 20 March 2021).

11. Gouda, S.; Luong, M.T.; Schmidt, S.; Bauer, J. Students and Teachers Benefit from Mindfulness-Based Stress Reduction in a School-Embedded Pilot Study. Front. Psychol. 2016, 7, 590. [CrossRef]

12. Martínez-Monteagudo, M.C.; Inglés, C.J.; Granados, L.; Aparisi, D.; García-Fernández, J.M. Trait emotional intelligence profiles, burnout, anxiety, depression, and stress in secondary education teachers. Personal. Individ. Differ. 2019, 142, 53-61. [CrossRef]

13. Smith, S.; Dutcher, K.; Askar, M.; Talwar, V.; Bosacki, S. Emotional competencies in emerging adolescence: Relations between teacher ratings and student self-reports. Int. J. Adolesc. Youth 2019, 24, 19-28. [CrossRef]

14. Mikulic, I.M.; Crespi, M.Y.; Radusky, P. Construcción y validación del Inventario de Competencias Socioemocionales para Adultos (ICSE). Interdisciplinaria 2015, 32, 307-330. [CrossRef]

15. Bisquerra, R. Educación emocional y competencias básicas para la vida. Rev. Investig. Educ. 2003, 21, 7-43. Available online: http:/ / bit.ly/2OTr0oq (accessed on 20 March 2021). 
16. Bisquerra, R.; Pérez, N. Las competencias emocionales. Educ. XXI 2007, 10, 61-82. [CrossRef]

17. Bar-On, R. Emotional Quotient Inventory (EQ-i): Technical Manual; Multi-Health Systems: Toronto, ON, Canada, 1997.

18. Graczyk, P.A.; Matjasko, J.L.; Weisberg, R.P.; Greenberg, M.T.; Zins, J.E. The role of the Collaborative to Advance Social and Emotional Learning (CASEL) in supporting the implementation of quality schoolbased prevention programs. J. Educ. Psychol. Consult. 2000, 11, 3-6. [CrossRef]

19. Saarni, C. Emotional competence. A developmental perspective. In The Handbook of Emotional Intelligence. Theory, Development, Assessment and Application at Home, School and in the Workplace; Bar-On, E.R., Parker, J.D.A., Eds.; Jossey-Bass: San Francisco, CA, USA, 2000; pp. 68-91.

20. Salovey, P.; Mayer, J.D. Emotional Intelligence. Imagin. Cogn. Personal. 1989, 9, 185-211. [CrossRef]

21. Mikulic, I.M.; Caballero, R.; Vizioli, N.; Hurtado, G. Estudio de las competencias socioemocionales en diferentes etapas vitales. Anu. Investig. Fac. Psicolog. 2017, 3, 374-382. Available online: http:/ / bit.ly/31No2Ot (accessed on 20 March 2021).

22. Rojas, F.; Escalante, D.; Bermúdez, L.; Amaíz, C. Competencias socioemocionales de los docentes en formación. Acción Pedagóg. 2017, 26, 120-129.

23. Piovano, N.; Solodovsky, M.; Pascuali, G. Competencias socioemocionales y estrés. Cómo se relacionan con el rendimiento académico en estudiantes de educación superior. Rev. Investig. Cient. Univ. Morón 2020, 3, 69-80.

24. Pegalajar, M.C.; López, L. Competencias Emocionales en el Proceso de Formación del Docente de Educación Infantil. REICE Rev. Iberoam. Sobre Calid. Efic. Cambio Educ. 2015, 13, 95-106.

25. Sporzon, G.; López-López, M.C. Evaluación de la inteligencia emocional y la conducta prosocial y su correlación en alumnado de Educación Primaria. Estud. Sobre Educ. 2021, 40, 51-73. [CrossRef]

26. Barrientos-Fernández, A.; Pericacho-Gómez, F.J.; Sánchez-Cabrero, R. Competencias sociales y emocionales del profesorado de Educación Infantil y su relación con la gestión del clima de aula. Estud. Sobre Educ. 2020, 38, 59-78. [CrossRef]

27. Llorent, V.J.; Zych, I.; Varo-Millán, J.C. Competencias socioemocionales autopercibidas en el profesorado universitario en España. Educ. XX1 2020, 23, 297-318. [CrossRef]

28. Zych, I.; Farrington, D.; Llorent, V.; Ttofi, M. Protecting Children through Anti-bullying Interventions. In Protecting Children Against Bullying and Its Consequences; Springer: Cham, Switzerland, 2017. [CrossRef]

29. Llorent, V.; López, M.; Gavilán, M. Culturas, políticas y prácticas de inclusión en las universidades: Enfoque desde la formación inicial del profesorado. In Interculturalidad: Un Enfoque Interdisciplinary. I Jornada Sobre Investigación e Innovación para la Interculturalidad; Rodríguez, L., Roldán, Y.A.R., Eds.; Universidad de Córdoba: Cordoba, Columbia, 2012; pp. 55-80. Available online: http:/ / bit.ly/317tkKM (accessed on 20 March 2021).

30. Amutio, A.; López-González, L.; Oriol, X.; Pérez-Escoda, N. Predicción del rendimiento académico a través de la práctica de relajación-meditación-mindfulness y el desarrollo de competencias emocionales. Univ. Psychol. 2020, 19, 1-17. [CrossRef]

31. López, V.; Zagal, E.; Lagos, N. Competencias socioemocionales en el contexto educativo: Una reflexión desde la pedagogía contemporánea. Rev. Reflex. Investig. Educ. 2020, 3, 149-160. Available online: https://bit.ly/3r8Ba1F (accessed on 20 March 2021).

32. Cook, C.R.; Miller, F.G.; Fiat, A.; Renshaw, T.; Frye, M.; Joseph, G.; Decano, P. Promoting secondary teachers' well-being and intentions to implement evidence-based practices: Randomized evaluation of the achiever resilience curriculum. Psychol. Sch. 2017, 54, 13-28. [CrossRef]

33. Saarni, C. The Development of Emotional Competence; Guilford: New York, NY, USA, 1999.

34. Fernández-Viciana, A.; Fernández-Costales, A. La autoeficacia percibida en los futuros docentes de inglés de Educación Primaria. Profr. Rev. Curríc. Formac. Profr. 2019, 23, 216-233. [CrossRef]

35. Tesouro, M.; Corominas, E.; Teixidó, J.; Puiggalí, J. La autoeficacia docente e investigadora del profesorado universitario: Relación con su estilo docente e influencia en sus concepciones sobre el nexo docencia-investigación. Rev. Investig. Educ. 2014, 32, 169-186. [CrossRef]

36. Covarrubias, C.; Mendoza, M. Adaptación y validación del cuestionario sentimiento de autoeficacia en una muestra de profesores chilenos. Univ. Psychol. 2016, 15, 97-108. [CrossRef]

37. Bandura, A. Perceived Self-Efficacy in Cognitive Development and Functioning. Educ. Psychol. 1993, 28, 117-148. [CrossRef]

38. Zimmerman, B.J.; Kitsantas, A.; Campillo, M. Evaluación de la autoeficacia regulatoria: Una perspectiva social cognitiva. Rev. Evaluar 2005, 5, 1-21. [CrossRef]

39. Chacón, C. Las creencias de autoeficacia: Un aporte para la formación del docente de inglés. Acción Pedagóg. 2006, 15, 44-54.

40. Tschannen-Moran, M.; Woolfolk, A. Teacher efficacy: Capturing an elusive construct. Teach. Teach. Educ. 2001, 17, 783-805. [CrossRef]

41. Cohen, J. Statistical Power Analysis for the Behavioral Sciences, 2nd ed.; Lawrence Erlbaum: Hillsdale, MI, USA, 1988.

42. Faez, F.; Valeo, A. TESOL teacher education: Novice teachers' perceptions of their preparedness and efficacy in the classroom. TESOL Q. 2012, 46, 450-471. [CrossRef] 